\title{
MIGRATION AND IDENTITY IN SOUTHWEST REGION OF CAMEROON: THE GRAFFIE FACTOR, c.1930s-1996
}

\author{
Walter Gam Nkwi ${ }^{1}$
}

\section{Introduction}

Issues pertaining to migration form part of the most salient topics in Africa today (IOM 2004). Although most of the literature tends to examine migration through the lenses of South-North movements, there have been considerable migrations within the continent of Africa itself (Bakewell \& De Haas 2007). Its ramifications are seen in social, cultural and political domains. The colonial rule affected the migration of people considerably because of the creation of mines and plantations and the existence of auxiliary services like drivers, gardeners, housemaids and messengers (Cordell \& Piche I996). The long run effect of such movements was the politicisation of identity. The recent upsurge of ivoirite denoting the "true Ivoirians" as opposed to the "other" in I995, and the makwerekwere in South Africa, coined to describe settler immigrants tickles us to the perennial issue of migration and politicization of identity which has been given birth by the colonial and post colonial regimes (Whitman, 2000). In the Central/West Africans state of Cameroon the concepts of allogenes and autochthones was evoked to include and exclude some of the citizens (Nouvelle Expression 1996; Awasum I998; Nyamnjoh and Geschiere I998). This article is a contribution to such ongoing debates which is pecked on migration and politicization of identity. Its specific contribution lies in the fact that is shows the layers of how migratory flows have contributed to the problematisation of identity. In most African states, settler immigrant population is merely mention and the net flow of these migrants into areas of identity contestation has not been given adequate attention. The pith

I Department of History, University of Buea, Buea, Cameroon. E-mail: nkwiwally@yahoo. com 
and ernel of this paper therefore argues that the colonial history of each of African states which precipitated new patterns of migration could contribute to a better understanding of recent politicization of identity. It appears to be the legacy of the colonial and post-independence institutions and elite actions that make identity a feasible political tool but underneath lays a rich history of migration which has hitherto not been excavated by scholars and researchers of Cameroon. If we are to understand migration and identity globally, we must first examine salient migratory flows over time and space.

This article focuses on the migration of Bamenda Grassfielders to the littoral quadrant of Cameroon and how they have in time and space maintained their identity in a socio-heterogeneous setting. It argues that although the concept of graffie which became a strong term in the lingo of most Cameroonians in I990s had its foundations stretched back into the I930s. Graffie is a creolized word which means people from the Bamenda Grassfields. Its meaning is sniping. It is sniping in the sense that it refers to people from the Bamenda Grassfields who are more backward as compared to the more civilized coastal people. It is also borne out of spite as the people who are more enterprising and entrepreneurial than the coastal people. Geographically, the region known as the Bamenda Grassfields is occupied with savannah and interspersed with forests in the valleys. The Germans code named it the Grassfields as opposed to the forest region. Despite the scholarly attention which has been given to the immigrants' population phenomenon by scholars in contemporary Cameroon, it has not been well historicized (Awasum I998; Konings and Nyamnjoh I997, 2003; Nyamnjoh and Geschiere I998.). This essay is an attempt to demonstrate that the name graffie had been constructed over the years due to sustained population migration from the Northwest region to the coastal region of Cameroon. The coastal region has a plantation complex as well as industries which acted as a cynosure that attracted the population from this area (Rudin I938:248; Fanso I989). The Bamenda region lacks any meaningful industries of any kind and so the ecology cannot harnessed its growing entrepreneurial population. Thus the lives of the people here is coloured by constant mobility.

Two concepts underscore the discussions in this article. These are identity and migration. Identity is a complex concept and appears to have gained its prominence only in modern sociological thought. Sociologists dealing with that concept in the I970 were pre-occupied with the "me" in trying to investigate the avenues through which interpersonal relations created the self in an individual. Cooper (2005), writing on identity, maintain that 'everybody seeks an identity', adding that 'identity is fluid, constructed and contested'. In other words identity is not bounded or rigid, it is created 
depending on time, context and circumstance. The authors also argue 'not for a more precise word to replace identity but rather for the use of a range of conceptual tools adequate to understand a range of practices and processes' (Cooper 2005) According to Cerulo (I997) many works have tended to refocus what obtained in the I970s by shifting attention from the individual to the collective identities'. While agreeing with Cerulo and others who belong to this school of thought, this article scrutinizes the practices and processes that create identities amongst the Bamenda Grassfielders while they are out of their areas of origin especially in southwest coastal Cameroon. What they held on that made them what they are or thought they were and how they blend with what their host also possess in the course of their migration is quite crucial in the essay.

There is no shortage of work on labour migration. Broadly speaking the red lines of the scholars could be categorized into three major parts. First, these scholars have shown us that migrations are not new to Africa and have been rural-rural; rural-urban, urban-rural. Secondly that Africa is a continent of considerable migration and people movements are dictated by political, social, economic and religious factors. Thirdly since the imposition of colonial rule in Africa, most migration has been dictated by labour. (Amin I974; Adepoju I977, I998, 2010, Harris I994; Davidson I954; Van Onselen I976).

In what follows in this article, I will sketch the history of migration of the ethnic groups of the region during the colonial and post colonial period while paying attention to migratory waves, and the factors which explain why the people migrated to the various places. The article will further examine the migrant-host relationship especially in coastal Cameroon and how the Bamenda Grassfielders have tried to hold tight to their identity while out of their area of origin in a melting pot of many cultures in the region. The article ends with a conclusion and a bibliography.

\section{Methodology}

According to Thomas (2002: 272), 'the importance and significance of methodology lies in the fact that the issue of what is studied is intimately connected with the question of how it is studied'. In the writing of this article I built and drew on my previous article (Nkwi 20I4) in which I sketched and analyse the migration of Bamenda Grassfielders to Europe, America and Asia showing how they have been constructing home out of home in those diasporic places. I also draw from other scholars and my article on identity which focuses on shifting identity on Cameroon football (Nkwi 20I4). Appreciably, I have added to my previous argument the graffie 
factor in the migratory waves and settlement of Bamenda Grassfielders in Southwest region of Cameroon.

The National archives located in Buea, Southwest region of Cameroon was useful. From that archive, I gathered the League of Nations reports as well as United Nations Trusteeship and visiting missions' reports. These reports show statistically how the migrants from the Bamenda Grassfields had been settling in the plantation coastal area over the years especially during the Mandate and Trusteeship periods.

My personal observation during the heydays of political liberalisation was also relevant. I have lived in the Southwest plantation coastal Cameroons since I993 when I was admitted into the University of Buea to read history at the undergraduate level. After that I was enrolled for the Masters program which I completed in record time and was recruited to teach back in the same Department. My discipline background and many years were to shape and sharpen my thoughts. During the long uninterrupted period I observed that Grassfielders, held very strongly to their identity by forming cultural associations and interestingly inter-married with people from other indigenous groups. They also held annual cultural meetings, print almanacs and appear in their traditional regalia. Some have opened beer parlours and give and give ethnic labels as tag names. For instance, the Afoa-Kom embassy; Moghamo drinking spot; Aghem Inn. All these denote a struggle to hold onto their identity.

\section{Locating the Bamenda Grassfields in the Geo-politics of Cameroon}

The term Bamenda Grassfields dates back to the period of the German colonization (I884-I9I6). It is used to connote that part of the hinterlands that was characterised with high altitude and grassy nature. Except for the forest galleries the area is full of beautiful grassy scenery. The indigenous population of the area immigrated from various directions and broadly speaking these groups can be placed under five major headings: Tikar, Widikum, Chamba, Tiv and Mbembe. Table one below shows the major groups of the region.

\section{Table 1: Different Ethnic Groups of the Bamenda Grassfields}

\section{Ethnic Group Population}

Kom, Nso, Oku, Mbiame, Wiya, Tang, War, Bum, Bafut,

Tikar Mbaw, Fungom, Mmen, Bamunka, Babungo, Bamessi, Bamessing, Bambalang, Bamali, Bafani, Baba, Bangola, Big Babanki, Babanki-Tungo 


\begin{tabular}{ll} 
Widekum & $\begin{array}{l}\text { Esimbi, Beba-Befang, Mankon, Ngemba, Ngie, Ngwo, } \\
\text { Mogamo, Meta }\end{array}$ \\
\hline Chamba & $\begin{array}{l}\text { Bali-Nyonga, Bali-Kumbat, Bali-Gangsin, Bali-Gashu, Bali } \\
\text { Gham }\end{array}$ \\
\hline Tiv & Aghem Federation \\
\hline Mbembe & Mbembe, Misaje, Mfumte
\end{tabular}

SOURCE: Paul Nchoji Nkwi (1987), Traditional Diplomacy: A Study of InterChiefdom Relations in the Western Grassfields, North West Province of Cameroon (Yaounde, Cameroon: Department of Sociology, University of Yaounde), 15

From the table above it could be seen that under the five major groups of the area the Tikars are the most populated in terms of the sub ethnic groups while the Widekum and Chamba come second. The least are the Tiv and Mbembe. These ethnic groups collectively constitute the Bamenda Grassfields. The lives of the people of this region is coloured by migration. In the pre-colonial period they mostly migrated to Northern Nigeria where they traded in kola-nut and in return bought spices and clothes. Exceptionally, they will also venture to the Bight of Biafra where they sold livestock and bought Dane guns and palm oil. During the colonial period they migrated to coastal Cameroon where there was a plantation complex. The post colonial period saw new migration destinations to Europe and America.

Much has been researched and written on the Bamenda Grassfields but from the perspectives of anthropologists, sociologists, and to a very less extent, historians (Chliver I96I, I963, I966, I967 and I981; Chilver and Kaberry I967 and I970; Kopytoff I973 \& I972 Nkwi 1976; Nkwi and Warnier I982; Kopytoff I972 \& I973; Rowlands I978; Pelican 2006). These readings as excellent as they appear to be are coloured by the backgrounds of the authors and although most of them implicitly dealt with migration they have not explicitly addressed the issue of migration and migrants' identity within a complex diverse milieu, a gap which this article sets out to fill. Their geographical migration during the colonial migration was mostly south bound.

\section{Southward Movements}

Generally, southward migration from the hinterlands of Africa South of the Sahara to coastal areas has been going for a very long time. Coastal cities and or towns became attractive to the youthful population during the colonial period and beyond for several reasons. One of such 
reasons was that these cities became the citadel of colonial administration and so many people migrated to work in such areas as clerks, messengers, cooks, drivers, prostitutes, labour to work on the roads and nurses.

The case of Cameroon was not an exemption. The creation of a plantation complex around the Mount Cameroon region with its rich volcanic soils began far back in the I88os, once the Germans discovered the rich soils. The area became a beehive of plantations of various types. There were palm plantations, bananas, pepper, cocoa and rubber. These plantations attracted labour both from the hinterland of Cameroon and beyond. There were French Cameroonians, Togolese, Nigerians, Ghanaians, Sierra-Leoneans, Liberians (Konings I998 and 200I; Rudin I938).

Besides, the colonial policies which were geared towards infrastructural developments also attracted migrants. The policy to construct roads which were to link the hinterlands and the coast brought in many migrants. The clerical services as well as auxiliary services of cooks, gardeners, housemaids, drivers, all combined to bring in migrants. As a result between the I930s and I96os, the Southwest Coastal Cameroon became a melting pot of many migrant cultures. Significantly, the plantations attracted by far the highest number of labour migrants in this region. Amongst the labour migrants, the Bamenda Grassfields migrants appeared to have surpassed most of the other migrants. Table two below shows the number of the migrants in waves between the wars. Essentially, the table shows the migrant population from the four main divisions of the Cameroon Province between I926 and 1938 and how the numbers were increasing or decreasing over the years.

Table 2: Plantation labour and Division of Origin, 1926-1938

\begin{tabular}{|c|c|c|c|c|c|c|c|}
\hline Year & Victoria & Kumba & Mamfe & Bamenda & $\begin{array}{l}\text { French } \\
\text { Came- } \\
\text { roonians }\end{array}$ & Others & Total \\
\hline 1926 & 780 & 2214 & 1063 & 1698 & 6330 & 63 & 12128 \\
\hline 1927 & 732 & 3230 & 1687 & 1965 & 5342 & 17 & 12953 \\
\hline 1928 & 434 & 3798 & 1441 & 3577 & 4925 & 233 & 14408 \\
\hline 1929 & 804 & 2887 & 1495 & 3183 & 4214 & 287 & 12866 \\
\hline 1930 & 305 & 2045 & 918 & 2064 & 3395 & 233 & 9040 \\
\hline 1931 & 267 & 1688 & 914 & 1905 & 2855 & 592 & 8319 \\
\hline 1932 & 308 & 1984 & 704 & 2264 & 4172 & 992 & 10994 \\
\hline 1933 & 361 & 1784 & 870 & 2413 & 4434 & 281 & 10123 \\
\hline
\end{tabular}




\begin{tabular}{|l|c|c|c|c|c|c|c|} 
Year & Victoria & Kumba & Mamfe & Bamenda & $\begin{array}{l}\text { French } \\
\text { Came- } \\
\text { roonians }\end{array}$ & Others & Total \\
\hline 1934 & 446 & 2097 & 1162 & 3271 & 4913 & 538 & 12417 \\
\hline 1935 & 689 & 2854 & 1650 & 4832 & 5251 & 415 & 15691 \\
\hline 1936 & 775 & 3292 & 2148 & 6066 & 5179 & 661 & 18120 \\
\hline 1937 & 1078 & 3153 & 2653 & 6322 & 4992 & 774 & 19590 \\
\hline 1938 & 1097 & 3253 & 3771 & 7800 & 4805 & 2509 & 25119 \\
\hline
\end{tabular}

SOURCE: These figures were gotten from the League of Nations Annual Reports found in the Buea National Archives, Buea, Cameroon for the years 1926 to 1938

From the table above several observations could be deduced. First within the other divisions of the Cameroon Province, the Bamenda division supplied quite a significant number to the plantations. This could be understood from the fact that the division was the largest in terms of geographical area and also it was the most populous of all the divisions. In contrast, the Victoria division with the smallest surface area supplied the least population. Another reason which has been advanced by researchers is that the land on which the plantations were opened was expropriated from the indigenous people of Victoria division with little or no compensation (Rudin I938). In disappointment they were not willing to work in the plantations. It could have as well been that the population was not as significant in numbers that of the Kumba division which was almost competing with Bamenda division in terms of the population.

The table also shows the multi-ethnic nature of the migrant labour which the Bamenda migrants found themselves. From I938 to I947 statistics of labour migrants are missing. This has been very hard to understand but it could be speculated that the international scenario which was tense in the late I930s leading up to the Second World War in I939 disrupted many things. One of these was the dead of the League of Nations in I939. It was only in I945 that a new international organisation, the United Nations Organisation was created. The Cameroon Development Corporation was created in I946 and from I948 to I969 the company religiously kept its records (Epale I985). Table three shows the growth of labour migrants during the trusteeship period and post independence. In the flux of many cultures, each one attempts out of consciousness to keep its unique features. It was in such circumstances that the Bamenda labour migrants attempted to maintain their identity in this complex situation. 
Table 3: CDC Divisional Analysis

\begin{tabular}{|c|c|c|c|c|c|c|c|}
\hline Year & Victoria & Kumba & Mamfe & Bamenda & $\begin{array}{l}\text { French } \\
\text { Came- } \\
\text { roons }\end{array}$ & Others & Total \\
\hline 1948 & 1529 & 3445 & 2146 & 4816 & 2662 & 3202 & 17910 \\
\hline 1949 & 1394 & 2665 & 2377 & 5745 & 2321 & 4538 & 19456 \\
\hline 1950 & 1291 & 2531 & 2301 & 6166 & 2426 & 4074 & 19005 \\
\hline 1952 & 1846 & 3856 & 3169 & 8941 & 2115 & 5508 & 25569 \\
\hline 1953 & 1028 & 2825 & 3073 & 8193 & 1958 & 7085 & 24970 \\
\hline 1954 & 820 & 2362 & 2930 & 8762 & 1582 & 7248 & 25030 \\
\hline 1955 & 658 & 2426 & 2806 & 7965 & 1369 & 6070 & 21664 \\
\hline 1956 & 573 & 1708 & 2323 & 6605 & 1005 & 5242 & 17793 \\
\hline 1957 & 524 & 1754 & 2251 & 6416 & 895 & 5498 & 17472 \\
\hline 1958 & 584 & 1685 & 2426 & 6944 & 861 & 6012 & 18501 \\
\hline 1959 & 588 & 1534 & 2341 & 6140 & 802 & 4944 & 16285 \\
\hline 1960 & 581 & 1537 & 2588 & 7246 & 808 & 4705 & 17468 \\
\hline 1961 & 588 & 1602 & 2664 & 7167 & 835 & 4238 & 17094 \\
\hline 1962 & 561 & 1585 & 2449 & 6936 & 732 & 3187 & 15430 \\
\hline 1963 & 548 & 1628 & 2280 & 6454 & 672 & 816 & 12378 \\
\hline 1964 & 565 & 1900 & 2268 & 6461 & 764 & 738 & 12716 \\
\hline 1965 & 589 & 1809 & 2414 & 6669 & 676 & 614 & 12651 \\
\hline 1966 & 556 & 1678 & 2248 & 6004 & 623 & 450 & 11559 \\
\hline 1967 & 611 & 1719 & 2305 & 6009 & 622 & 422 & 11688 \\
\hline 1968 & 716 & 1976 & 2350 & 6516 & 690 & 316 & 12564 \\
\hline 1969 & 950 & 2312 & 2933 & 7487 & 753 & 310 & 14745 \\
\hline
\end{tabular}

SOURCE: CDC Annual Reports

\section{The Migrants'-Hosts Relationship and the creation of identity}

The numerical superiority of the Bamenda Grassfielder migrants determined their relationship with their hosts especially in the plantation area. The plantations in particular have attracted a lot of labour migrants from the Bamenda Grassfields over time and space as tables two and three have shown above. The Bamenda Grassfielders were overall majority migrant population in the plantation region. From the beginning the migrants and host relationships was cordial between the southwest minority and Northwest majority. Researchers who have work on estate labour have 
reached a consensus, that all was fine (Ardener et.al. I960; Delancey I973; Konings 1996, I998, 2001). According to these authors both groups exercised a high level of cordiality in inter-ethnic relations encapsulated in the membership of churches and trade unions. They also coordinated to fight any form of labour exploitation like the CDC workers strike in I940s (Konings 200I). The government policy and church to promote a multiethnic state helped in cementing relations between the Bamenda Grassfields' migrants and their host. Their language which is Pidgin English, a lingua franca of creole origin helped in keeping the two groups together. These 'horse-riding' relations did not go on sine die.

The effects of the continuous increase of the Bamenda migrants in the Southwest plantations soon turned dramatic and sour. Crucial to the souring of relations was the ethnicity and politics of identity and belonging which the government of Cameroon was playing in the I990s. (Nkwi 2006). While initially the Bamenda migrants who had migrated to the plantations worked and returned to their areas of origin in the long run many preferred to retire and stayed on in the coastal zones. Reasons for such choices could be found in the fact that they preferred the fertile soils; modernity than their "backward villages". This drove most workers to find accommodation in nearby villages and towns which were however near to the plantations. The Bamenda migrant population was soon joined by friends, relatives and in-laws and this mainly because of fertile land which they were given by the host to cultivate. This soon swelled the populations of Bamenda migrants. The land that was initially bought at a giveaway prices soon became commercialised and so the settler population mostly the Bamenda migrants became so aggressive in getting the land.

The resulting effect of all these was obvious. The host population started envying the Bamenda migrants. This was because of the entrepreneurial nature of the settlers from Bamenda and also because the settler population had no respect for the local authorities and laws of the host. They were also envied because of their steady seduction of local women and their unwillingness to meaningfully carry out any investment in the host community. The general perception of the Bamenda migrant was that the Bamenda Grassfielders were only interested in the exploitation and dominating local population, while continuing to be loyal to their own ethnic group, which was ultimately evidenced by their frequent desire either to return home at the end of their working life or to be buried in the land of their ancestors or formed ethnic associations in which they practiced their culture.

In the I990s following the re-democratisation process the government of Cameroon decided to exploit this antagonism in her divide- 
and rule policy. The government gave birth to a new constitution which was an anti-thesis of the I972 which guaranteed the protection of all citizens of the country to freely settle wherever was their choice in Cameroon. The I996 constitution rather promised state protection for all the minorities as the elections were approaching. What was striking was not that the constitution had promised to protect minorities. Rather it was the fact that it had stretched the traditional meaning of minority to such exaggerated proportions beyond the mental imaginations of any person. It appeared and more so certain that the minority groups will have to rely on the government for survival. The South westerner did just that against the Bamenda migrant majority settler and shifted towards the ruling government and its party against the opposition. Of course the new constitution had boosted the protection of the South westerner and poured petrol to the already existing tension flames between the Southwest minority and Bamenda immigrants. Yet the population of the migrants from Bamenda were overwhelming even to tilt the elections results in the favour of the opposition with its stronghold based in Bamenda.

Thus during the 26 January 1996 municipal elections the Southwest pro-ruling party elites lost to the SDF, which was the main opposition party and having Bamenda as its base swept most of the key urban constituencies of the region. The wheel of the impact of Bamenda immigrants had turned full circumference. Asked over a radio interview why this happened, the highest civil servant of the region, His Excellency, Governor Oben Peter Ashu responded that it was because of the settler immigrant population from the Northwest region of Cameroon. Immediately, the Bamenda migrants were branded as "come-no-goes". In other words they were likened to scabies, a stubborn skin affliction which last for a long time. The insinuation by the governor that opposition won many constituencies because of migrant population remains a debate. What is certain is that the demographic weight of Bamenda Grassfielder migrants' in the region was telling.

Put in proper perspectives, the Bamenda Grassfielders and South westerners have deeper historical antagonism which predates the I990s. In I950s VIKUMA was formed which stood for Victoria, Kumba and Mamfe, the three divisions of the Cameroons under the British colonial administration (Nkwi 2006). This was to fight against the Kamerun National Democratic Party (KNDP) which was based in the Bamenda Grassfiekld zone and which was accused for victimising people from the forest region. These were the handiwork of political and traditional elites in these divisions. In the I990s its parallel was the Southwest Elites Association (SWELA). In the wake of political pluralism in I990, the political elites of the Southwest region in an attempt to frustrate the ambitions and will of strangers who 
opposed the status quo ante formed an association, SWELA, in I99I which they described as apolitical (Nkwi 2006). Yet its underground objectives suggests that it was a political association formed to resists the Bamenda Grassfields people who were filling in the Southwest region. In the midst of all these associations, the graffie man resisted, by staying and hanging onto his identity. The next section focuses on how the graffie man/woman has been creating and coping with their identity in the midst of multifarious ethnic groups in the littoral quadrant of Cameroon.

\section{The Creation and coping with Identity}

In the midst of multiple cultures the Grassfielders set to maintain their identity. One of the ways which led immigrants to feel and belong was ethnic and cultural associations. Scholars have researched on the formation of tribal and cultural associations (Little I972; Geschiere \& Gugler I998: 309-319; Gugler 2002). Below is the profile of an indigenous group, Kom, a domineering indigenous group in the Bamenda Grassfields whose formation, experience and modus operandi is representative of one of the main arguments in this article.

Kom is the second largest ethnic group in the Bamenda Grassfields (Fanso I989), whose population had been migrating to the plantations is Kom. In I966, the Kom migrants formed an ethnic association known as the Kom Union. Its head quarter was in Buea. The membership of that association was opened to civil servants and migrant labour from Kom living not only in Buea but also in Kumba, Victoria, Tiko, Mutengene, all coastal areas which attract migrants from the Bamenda Grassfields. A significant and relevant thing which concerns the association is the fact that Kom people had started practising their culture through song and dances, of which the most popular was njang. Njang is traditional folklore music. Most of the time the music and songs referred to important historical events. Those who danced and sang njang were men and women, girls and boys. Traditional instruments like metal gongs and a small drum are used during the choreography (Nkwi 20Io). The venue of the meeting which was in the compound of the oldest Kom person was also known as Kom palace. And the compound was a meeting point for all Kom who were found in Mamfe, Kumba, Buea and Victoria.

Identity was the most relevant thing that underscored such association and monthly meetings were held. Monthly contributions and condolence fees was compulsory. Above all there was a constitution which had its by-laws, scrupulously followed by their members. Just as Schipper (I999: 2) has observed that 'throughout the centuries, human beings have 
created binaries, devising images of themselves as opposites of others and have embedded such images in stories, songs and other forms of expressions', Kom people also drank palm wine (a milky-like liquid tapped from a palm tree) and ate their traditional meals which consist of fufu corn and roast chicken (abain ni gwei e katign e). In that meeting Kom socialized as they did in their villages. By doing so they included and excluded others who did not belong to their group. The point here is that Kom people were identifying themselves through their culture but outside of Kom and at the same time constructing a home from home in the course of their geographical mobility.

Wherever the Bamenda Grassfielders found themselves in the coast or elsewhere in Cameroon in general, they remained loyal to their identity. Taming and domesticating these places and spaces as in plantations and coast signified the creation of new homes, seen and understood as a way of coping with life and culture outside the areas of origin. The final place was home where they would eventually prefer to end their lives. Here they can be viewed as 'essentialist' for the lack of a better word, from their garments. But in other respects they change as they consumed new commodities in new locales. The need to Komify in the case of Kom, or Nsoify in the case of Nso or to Wehify in the case of Weh or Isuify in the case of Isu in distant places suggests the notion of 'virtual' and 'real' a situation which could be quite ambiguous.

The real Kom or Nso or Aghem or Weh was the one that had geographically mapped out boundaries. The ethnic groups formed tribal and/or cultural associations which resemble those that were found in their areas of origin. This was not new in the history of such associations in Africa. But what was important and relevant as far as their associations were concerned was that they created the feeling of belonging to home and thereby through such associations created home out of home. Furthermore, such associations also existed to remind those who have not migrated that their kith and kin who have migrated should not be forgotten. As a matter of fact, these associations participated in developmental projects back at home. When the sojourn of the migrants was over, they could be welcome at home as heroes and heroines because they had at least participated in keeping the society move forward in their absence. Some excellent works have been conducted elsewhere in Africa in what has generally be lumped up as 'rural-urban connection' (Gugler I96I).

Such associations existed in the minds of the migrants, who belonged to networks of belonging and solidarity. The whole issue is far from simple. While a student in Holland I attended several meetings of the Bamenda Grassfielders. The Kom people always wanted to confirm their 
Komness. There were many who could barely speak the Kom language. Some were married to European wives. That prompted us to critically engage in the question of Kom identity, not as a geographical one but the one that identified Kom people as Kom. The essentiality of Kom identity does not lie in language alone or culture per se but more in the craving for belonging. These are indicators that over the years the movement of people in and out of the Bamenda Grassfields and their encounters have added a new dimension to their identity. As Nyamnjoh (20I4) has argued concerning cultural identity '... identity could be imagined and real ... in a way it is an invitation to contemplate a de-territorialised mode of belonging where relations matter more than birthplaces in whether or not one feels at home'. Pelican further maintain that,

... pre-colonial and post colonial identities in Cameroon and throughout Africa are complex, negotiated and relational experiences that call for a nuanced rather than an essentialist articulation of identity and belonging. With the Tikar... as well as any group in Cameroon and Africa being authentic is a function of the way race, place, culture, class and gender define and prescribe, include and exclude. These social hierarchies assume different forms depending on encounters, power relations and prevalent notions of personhood, agency and community (Nyamnjoh 20I4 \& Pelican 2006).

It can be argued thus that most of the Bamenda Grassfielders' migrants' identity has started to shift from the essentialist standpoint that maintained them as being frozen in geographic terms. Their continuous creation of identity in the coastal plantations also brings up the primordial argument which according to Appadurai (2006) maintains that 'all group sentiments that involve a strong sense of group identity, of 'we-ness', draw on those attachments that bind small, intimate collectivities, usually those based on kinship or its extensions. Ideas of collective identity based on shared claims to blood, soil or language draw their affective force from the sentiments that bind small groups' Appadurai here was referring to the thesis that people who have a strong sense of togetherness derive their inspiration from kinship, language and geographical origin.

\section{Conclusion}

Migration the world over is not a new phenomenon. It spans the entire life of humanity. Many factors have been responsible for the movement of people from one region to the other. In pre-colonial African societies people migrated in search of food, trade by barter and sometimes 
because of natural disasters. The colonial migrations were more dictated by the colonial policies which included amongst others the opening of plantations and mining of diamonds, bauxite, manganese and gold. The colonial administration also imposed taxes which Africans were condemned to pay in order for the colonial machinery to be greased. Education and the opening of new public services all combined individually and collectively to caused migration of people in different directions.Labour migration thus became one of the dynamics which underscored migrations during the colonial period. In the post colonial period migratory trends which had been put in place by the colonial administration continued albeit with some changes.

In Cameroon, the opening of a plantation complex in the littoral quadrant attracted the migration of labour from the Bamenda Grassfields. This region which became a labour exporting zone saw its people moving down to the plantations in their numbers. Like their counterparts from other regions of Cameroon, the Grassfielders set out to construct their identity in the midst of many other cultures. They held on to the key cultural features of their homes and thus were constructing home out of home. This article has concluded that despite the many people and their cultures in the coastal Southwest Cameroon the Bamenda Grassfielders have held onto their identity. It further contended that the concept graffie which became quite fashionable in I990 to pejoratively mean Bamenda man and ambiguously mean any enterprising and virile people had deeper historical roots which has not been accorded in migratory history of the phenomenon. As the world is becoming more and more interconnected with accelerated mobility of human beings, ideas and cultures, the implication is that unique identities are becoming under threat and runs the risk of being eradicated. As the article has amply demonstrated, while the Bamenda Grassfielders inter marriage with hosts and other related persons one can hardly talk about confined and frozen identity. And thus it will be appropriate to see identity like Cooper as a constructed phenomenon which is fluid and contested. On a final note the paper has just started the study of the identity construction of the Bamenda Grassfielders in the coast. The study of other labour migrants from other parts of Cameroon might show some parallels as well as similarities. Whatever the case may be, whether constructed or fluid, identity is so strong a phenomenon that cannot be ignored in writing the history of migrantion of any region of the world. 


\section{REFERENCES}

Adepoju, Aderanti. 20I0. International migration within, to and from Africa in a Globalized World. Lagos: Sub-Saharan Pub and Traders.

. I977. "Migration and development in tropical Africa: Some research priorities". African Affairs, Vol. 76, No. 303: 210-225

. I998. "Linkages between internal and international migration: The African International Social Science Journal, Vol. 50, No. 157:387395 .

20I0. International migration within, to and from Africa in a globalized world. Lagos: University of Lagos Press

. 1977. "Migration and Development in Tropical Africa: Some Research Priorities". African Affairs, Vol.76, No.303:210-225.

2008. Migration in sub-Saharan Africa. Uppsala: Nordickinstitute.

Amin, Samir. I974. Modern Migrations in Western Africa. London: Oxford University Press.

. I974. Modern migrations in Western Africa London: Oxford University Press

Appadurai, Arjun. I996. Modernity at Large: Cultural Dimensions of Globalization. Minnesota: University of Minnesota Press.

Ardener, Edward; Ardener, Shirley \& Warmington, W.A. I960. with a contribution by M.J Ruel, Plantation and village in the Cameroons: Some economic and social studies. Oxford: Oxford University Press

Ardener, Edwin. I996. "The plantations and the people of Victoria”. In: Shirley Ardener, ed., Kingdom Kingdom in Mount Cameroon: Studies in the history of the Cameroon coast, 1500-1970.(Oxford: Oxford University Press, pp. 243-266;

Awasum, Nicodemus. I998. "The Development of Autonomist Tendencies in Anglophone Cameroon pp. I63-I83." Journal of Third World Studies. Vol. Xv, No. I: I63-183

Bakewell, Oliver and de Haas, Hein. 2007. "African Migrations: continuities, discontinuities and recent transformations". In Patrick Chabal, Ulf Engel and Leo de Haan (eds.) African Alternatives. Leiden: Brill: 95-II8.

Black, Richard; King, Russel and Tiemoko, Richmond. 2003. "Migration, return and small enterprise development in Ghana: a route out of poverty" Sussex Migration Working Paper no.9: Centre for Migration Research,pp. I-2I 
Cerulo, Karen A. I997. "Identity Construction: New Issues, New Directions" Annual Review of Sociology, Vol.23: 385-409.

Chilver, Elizabeth M. 1963. "Native administration in West Central Cameroons, I902-I954"In: K. Robinson \& F. Madden, eds. Essays in imperial government. (Oxford: Oxford University Press, pp. Ioo-Io8; . I966. Zintgraff's exploration in Bamenda, Adamawa and the Benue lands,1889-1892 (Buea: Governement Printing Press. . I970. "Chronology of the Bamenda Grassfields" The Journal of African History, Vol. II, No. 2: 249-257; . I967. "The kingdom of Kom in West Cameroon". In: Daryll Forde \& P.M.Kaberry, eds. West African kingdoms in the Nineteenth Century. (Oxford: Oxford University Press, pp.I23-I45.

. I96I. "Nineteenth century trade in the Bamenda Grassfields". Afrika und Uerbersee, xiv, 4: 233-258;

. I97I. "Chronological synthesis: The western region, comprising the western grassfields, Bamum, the Bamileke chiefdoms and the central Mbam”. In: Claude. Tardits, ed., The contribution of ethnological research to the history of Cameroon cultures. Paris: Karthala, pp. 453-475.

Chilver, Elizabeth M and Kaberry, Phyllis M. I970. Traditional Bamenda: The pre-colonial history and ethnography of the Bamenda Grassfields. Buea: Government Printing Press.

Cooper, Frederick. 2005. Colonialism in Question: Theory, Knowledge, History. Berkeley/LosAngeles/ London: University of California Press.

Cordell, Denis D.; Gregory, Joel W. \& Piche, Victor. I996. Hoe and wage: A social history of a circular migration system in West Africa. Boulder,CO: Westview Press.

Davidson, R.B. I954. Migrant labour in the gold coast. Achimota: University of Legon Press

Delancy, Mark.W. I973. Changes in Social Attitudes and Political Knowledge among Migrants to Plantations in West Cameroon. Indiana: Indiana University.

Epale, Simon Joseph. I985. Plantation and Development in Western Cameroon 1885-1975: A Study in Agrarian Capitalism. New York: Vantage Press.

Geschiere, Peter \& Nyamnjoh, Francis Beng. 200I. "Capitalism and Autochthony: the Seesaw of Mobility and Belonging,"pp.I77-I94. In John L. Comaroff and Durham N.C. (eds) Millennial Capitalism and the Culture of Neoliberalism. New York. Duke University Press.

Geschiere, Peter \& Gugler, Josef. I998. "Introduction: The Urban-Rural 
Connection, Changing Issues of Belonging and Identification" Africa: Journal of the International African Institute, vol.68, no.3:309-3I9. Gugler, Josef. I96I. "Life in a Dual System: Eastern Nigerians in Town, I96I” Cahiers D’Etudes Africains, Vol.xi, No.43: 400-4I9.

. 2002. "The Son of the Hawk Does Not Remain Abroad: The Rural-Urban Connection in Africa” African Studies Review, Vol.45, No.I: 2I-4I.

Harris, Patrick. I994. Work, culture and identity: Migrant laborers in Mozambique and South Africa, c. 1860-1910: Social History of Africa. London: Oxford University Press.

IOM. 2004. International Organisation for Migration.

Konings, Piet. I996. "Chieftaincy, Labour Control and Capitalist Development in Cameroon." Journal of Legal Pluralism and Unofficial Law, No.37-38, 329-346

. 200I. "Mobility and exclusion: Conflicts between autochthons and allochtons during political liberalization in Cameroon”. In: M. de Bruijn, R. Van Dijk \& D. Foeken, eds. Mobile Africa: Changing patterns of movement in Africa and beyond. Leiden: Brill, pp.I69-I94.

. I988. Uniliver estates in crisis and the power of organisations in Cameroon. Hamburg: Lit Verlag

Konseiga, Adama. 2005. "New Patterns of Migration in West Africa” Stichproben Wiener Zeitschrift fur Kritsche AfrikasStudien,Vol.I, Nr.8, pp.23-46;

Little, Kenneth. I972. "Voluntary Associations and Social Mobility Among West African Women" Canadian Journal of African Studies, vol.6, No.3:278-88

Nkwi, Walter Gam. 2010. Voicing the Voiceless: Towards Filling Gaps in Cameroon History, 1959-2009. Mankon,Bamenda: Langaa Research and Publishing House.

. 2006c."Elites, Ethno-regional Competition in Cameroon, and the Southwest Elites Association (SWELA), I99I-I997"African Study Monographs, Vol.27, No.3:I23-I43.

Nkwi, Paul Nchoji. I982. Traditional diplomacy: A study of inter-chiefdom relations in Western Grassfields Northwest Province of Cameroon. Yaoundé: Department of Sociology Press.

Nyamnjoh, Francis B. 2005. "Images of Nyongo amongst Bamenda Grassfielders in WhitemanKontri”. Citizenship Studies, Vol. 9, No. 3: 24I269.

Rowlands, Michael. I978. "Local and long-distance trade and incipient state 
formation in the Bamenda plateau in the late Igth century". Paideuma, No. 25, I-I9.

Rudin, Harry. I938. The Germans in Cameroon: A Case Study in Modern Imperialism. Yale: Yale University Press

Schipper, Mineke. I999. Imagining Insiders: Africa and the Question of Belonging. London: CASSELL.

Thomas, N. 2002. "History and Anthropology"pp.272-295. In Allan Barnard and Jonathan Spencer. Eds. Encyclopaedia of Social and Cultural Anthropology. London and New York: Routledge.

Van Onselen, Charles. I976. Chibaro: African mine labour in Southern Rhodesia, 1900-1933. Johannesburg: University of Wits Press

Veronika, Bilger, \& Kraler, Albert (eds.). 2005. "African migrations: Historical perspectives and contemporary dynamics". Special Issue: Vienna Journal of African Studies, Vol. I, No. 8:I-329.

Warnier, Jean-Pierre. 2012. Cameroon Grassfields Civilisation Mankon, Bamenda : Langaa RPCIG

Whitman, Jim (ed) 2000. Migrants citizens and the state in Southern Africa. London: University of Oxford Press.

\section{ABSTRACT}

This article focuses on the dynamics of internal migration taking the case of Bamenda Grassfielders' migrants in coastal Cameroon and stresses on how such migrations gave rise to the identity puzzle between those who were branded as the graffie and their host. It questions how the politicization of identity can be understood within the historical and political dynamics of Cameroon. The article further maintains that at the onset of the British colonial rule many people from this region migrated to the industrial complex of coastal Cameroon as plantation labour as well as auxiliary labour in other colonial services. After work in these services they retired and became enterprising to the chagrin of their host. They were thus derogatorily branded as graffie. Using the concept of identity in migration the article questions why and how the graffie have coped with their identity in heterogeneous spaces like the South west region of Cameroon.

\section{KEYWORDS}

Migration; Identity; graffie; Cameroon. 